\title{
Modeling Escorting School Trips by Employed Parents Based on Latent Variables
}

\author{
Sara Mohajerani ${ }^{1}$ \\ AmirReza Mamdoohi² | armamdoohi@modares.ac.ir
}

\begin{abstract}
Trips are an inseparable aspect of our lives, and nowadays their purposes have been changed and their number has increased. Most of the trips are done by cars, which make lots of harmful influences on our environment (such as pollution, global warming, and lack of energy sources), and they also bring about negative impacts on the economy and society. In order to have sustainable development, transportation managers should make long-term investments and policies on public transportation and active travel modes. In view of that, in addition to socio-economic variables and attributes of trips, we investigate the effect of latent psychological variables such as attitude, perceived behavioral control, subjective norms, and intention on escorting elementary school trips by employed parents. For this purpose, we analyzed and modeled the data of 4000 questionnaires filled by the parents of students of Tehran's schools. Results obtained from estimating and calibrating the ordered and multinomial Logit models, show that the variables of perceived distance to school, children age, frequency of using the car to school, similarity between start time, and route travel in work and educational trips, intention, perceived behavioral control, existence of a proper person in the family for escorting children, suitable evaluation of one other person in family by parent and choosing public mode in case of similarity between start time, and route travel in work and educational trips in both models were statistically significant. Therefore, we can increase motivation by carrying out programs such as: explaining the importance of environmental and traffic issues, encouraging students and parents to do Supervisional Walking Bus (SWB), building residential settlements near parents' office and students school, creating safe routes for walking and cycling and increasing the safety of neighborhoods; these programs can increase the probability of using active modes by students.
\end{abstract}

Keywords: Escorting School Trip, Latent Psychological Variables, Escorting School Trips, Discrete Behavioral Choice Models, Traffic Issues.

JEL Classification: R41,R4 ,R.

1. M.A in Transportation Planning, Institute for Management and Planning Studies, Tehran, Iran.

2. Associate Professor, Faculty of Civil \& Environmental Engineering, Tarbiat Modares University, Tehran, Iran, (Author Corresponding). 


\section{مدل همر اهى دانش آموزان دبستانى در سفر تحصيلى توسط والدين شاغل؛ با تاكيد بر متغير هاى ينهان}

سار امهاجرانى

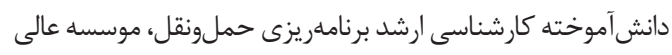

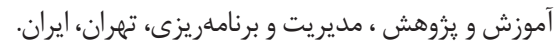

armamdoohi@modares.ac.ir

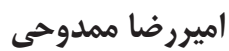

دانشيار دانشكده مهندسى عمران و محيطزيست، دانشكاه تربيت

مدرس، تهران، ايران (نويسنده مسئول).

مقاله بزوهشى

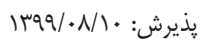

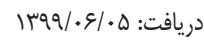

"جكيده: كاهش سفرهاى فعال و مستقل مسئله مشتر ك كلانشهرهايى است كه در آن خودروى

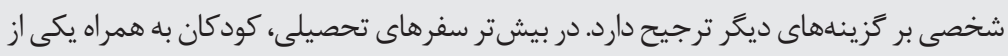

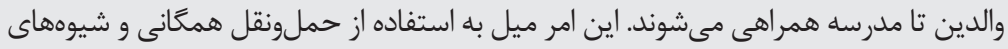

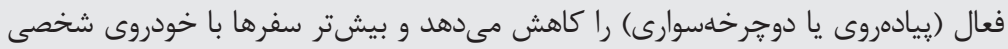

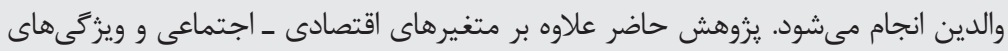

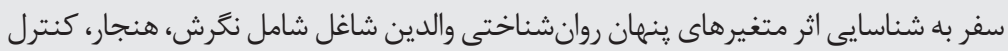

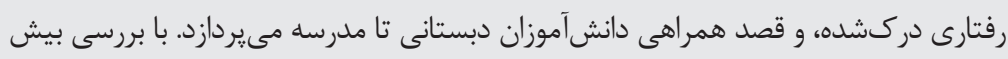

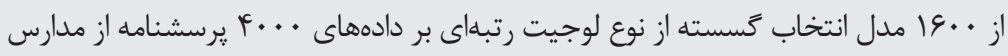

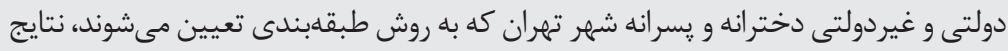

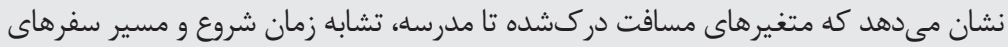

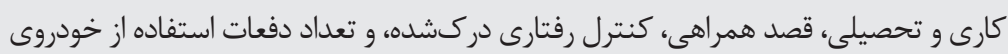

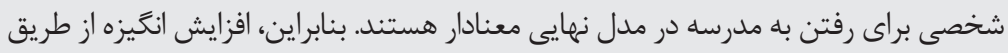

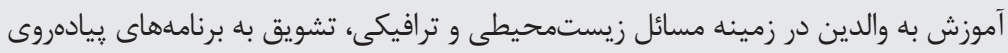

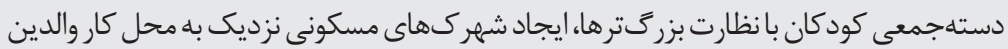

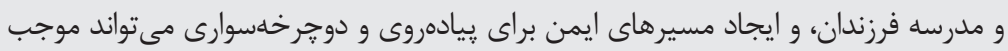

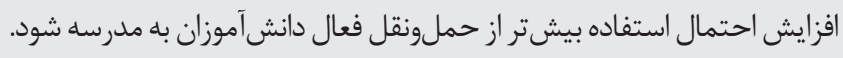

كليدوازهها: سفر دانشآموزان دبستانى، متغيرهاى ينهان روانشناختى، مدلهاى انتخاب

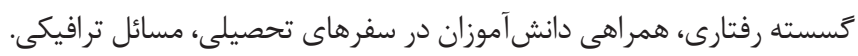

طبقدبندى R41, R4, R :JEL. 


\section{مقله}

در بيشتر سفرهاى تحصيلى دانشآموزان دبستانى كه سهم بالايى از سفرهاى اوج روزانه

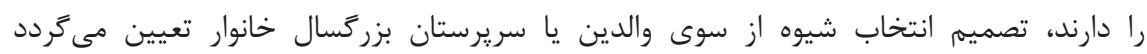
(McMillan, 2007) را در انجام اين سفرها كاهش مىدهد و بيشتر كودكان بهجاى ييادهروى يا دوجرخهسوارى

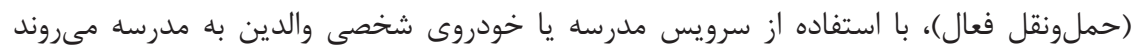
(Westman et al., 2017; McDonald \& Aalborg, 2009) كودكان، نبود استقلال آنها، ايجاد ازدحام، آلودگى هوا، و استفاده نكردن از شيوهاى فعال حملونقلى مىشود. بنابراين، بررسى رفتار تصميمگيرى والدين در سفرهاى تحصيلى از مهممترين موضوعها در حملونقل بهشمار مىرود.

شكاف موجود در ادبيات اين است كه در يزوهش هاى انجامش بدهد در ايران رفتار همراهى دانشآموزان

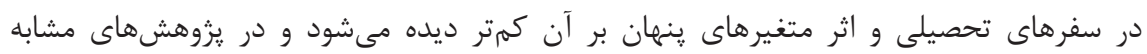

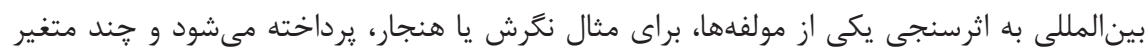

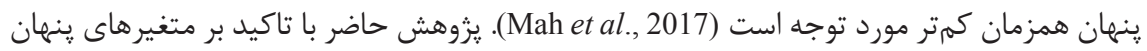

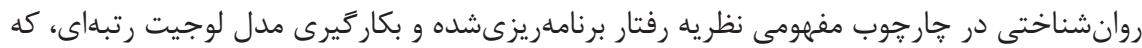

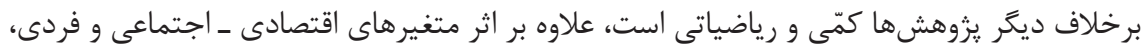

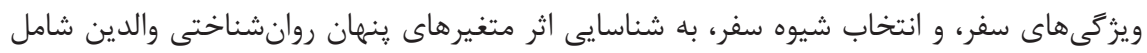
نكرش، هنجار، كنترل رفتارى دركشده، و قصد و متغيرهاى تركيبى كه در براى اولين بار در اين

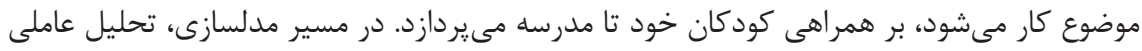

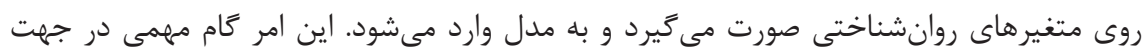

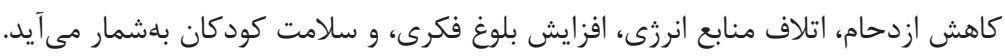
در يزوهش حاضر يس از بيان ضرورت مسئله، به مرور مبانى نظرى ڤرداخته مىشود. سيس به به روش انجام و توصيف دادههاى يزوهش اشاره مىشود. در يايان، مدلسازى و تحليل اثر حاشيهاى تمام متغيرهاى مستقل انجام مىشود، و بحث و نتيجه گيرى ارائه مى گردد. 


\section{مبانى نظرى يزوهش}

در اين بخش، ابتدا به دستابندى متغيرهاى مختلف اثر گذار بر همراهى يرداخته مىشود (شكل ()،

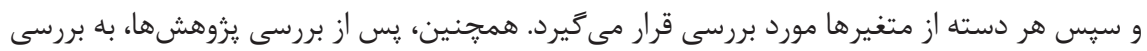
متغيرهاى جديد روانشناختى همجون نگرش، هنجار ذهنى، كنترل رفتارى دركشده، و قصد همر اهى در ديدگاه نظريه رفتار برنامهريزىشده سفرهاى تحصيلى كودكان دبستانى يرداخته مىشود.

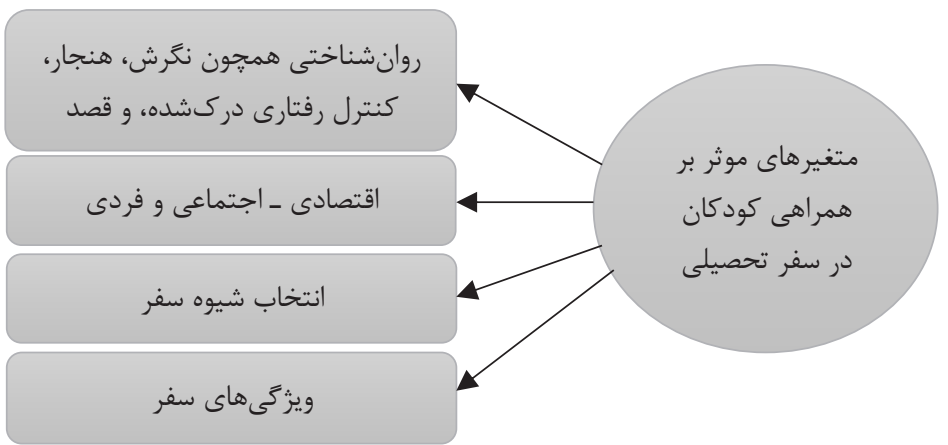

شكل ا: متغيرهاى اثر كذار بر همراهى كود كان

متغيرهاى اقتصادى ـ اجتماعى و جمعيتشناختى به جهار دسته كلى ويزگگ هاى دانشآموز اعم

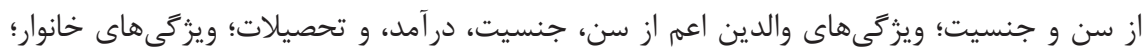
و ويزگى هاى مدرسه تقسيم مىشوند. جنسيت والدين در انتخاب شيوه سفر تحصيلى كودكان موثر

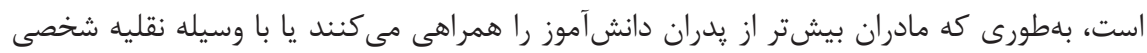

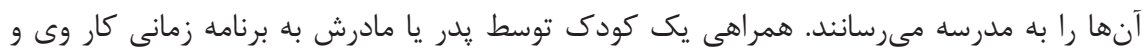
به محدوديتهاى مكانى او مانند نسبت قرارگيرى محل كار او به محل مدرسه و خانه بستگى دارد

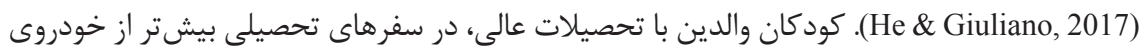
شخصى به مدرسه برده مىشوند (Mehdizadeh et al., 2016). يزوهشها نشان مى نىهند كه افزايش درآمد به افزايش احتمال استفاده از وسيله نقليه شخصى منجر مى مردد (Hensher et al., 2005). 
متغير هاى ساختار محيطى

متغيرهاى ساختار محيطى عبارتاند از الكوى كاربرى زمين موجود در محلات، زيرساختها

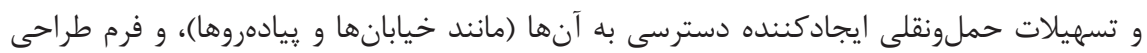
شهرى (بُعد زيباشناختى، ويزَگىهاى فيزيكى و عملكردى بناها و معابر) (مهدىزاده و ممدوحى،

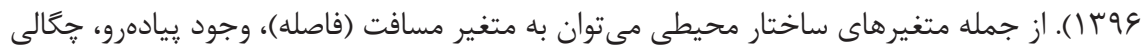

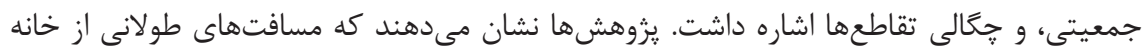
تا مدرسه و ازدحام، سفرهاى فعال و مستقل (بدون نظارت بزرگترها) را محدود مى كند و در مقابل،

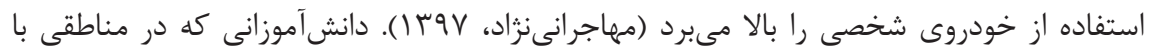

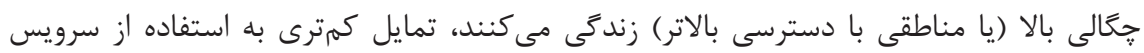
مدرسه دارند (Smith et al., 2020; Evenson et al., 2003).

\section{متغير هاى ويثزَى سفر}

متغيرهاى اين دسته شاخصهايى است كه بر انتخاب شيوه سفر، تحصيلى يا غير آن، اثركذار است. از جمله متغيرهاى بررسىشده در اين مورد مىتوان به هدف سفر، ذهان زمان آغاز سفر، زنجيره

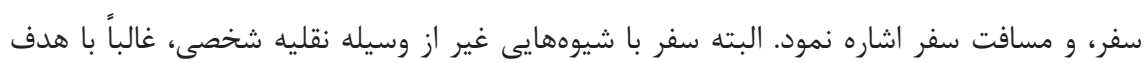

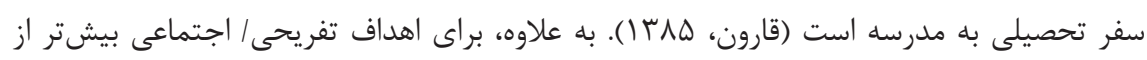

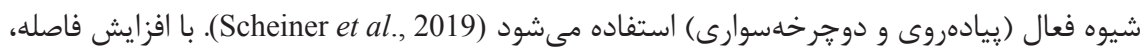
شيوههاى سريعتر حملونقلى با استقبال بيشترى مواجه مى شوند. همجنين، وسيله نقليه شخصى تارئ فاصله • ب كيلومتر، شيوه غالب براى تردد روزانه است (Stark et al., 2018).

\section{متغير هاى روانشناختى}

از مهمترين متغيرهاى اثرگذار بر همراهى دانشآموزان در سفرهاى تحصيلى و انتخاب شيوه

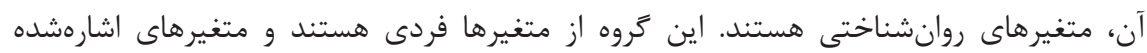

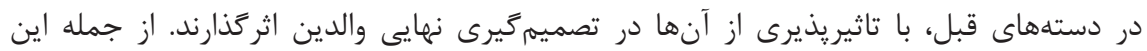

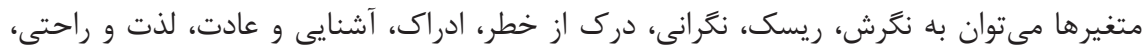

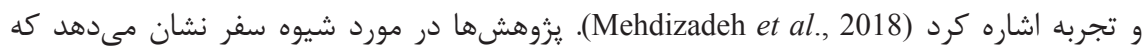


نكرشها (در اينجا به اين اشاره دارد كه والدين به شيوهاى مانند خودروى شخصى خه درجهاى از مطلوبيت را مىدهند)، انتخاب شيوه سفر را بيش از هر متغير ديخرى تحت تاثير قرار مىدهند (Westman et al., 2017) مزاياى بيشترى در اين خصوص ادراك نمايند، فرزندان آنها با احتمال بيشترى از حمل حملونقل فعال

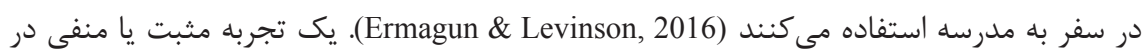
كذشته مىتواند در انتخاب شيوه موثر باشد. در برخى يزوهشها، تجربه به عنوان يك ظرفيتى كه

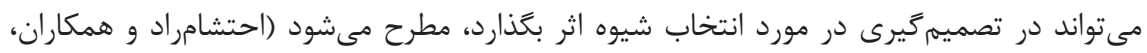

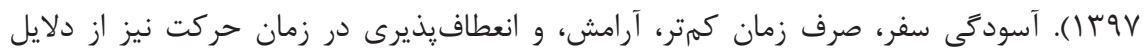
وابستگى به استفاده از خودروى شخصى در اين سفرهاست (Yarlagadda \& Srinivasan, 2008). در اين بخش، رويكردهاى روانشناختى مختلف انتخاب شيوه سفر از ديدگًاه دى ويته و همكاران'

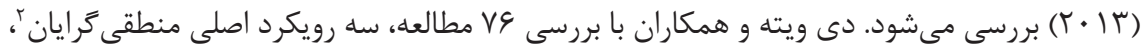

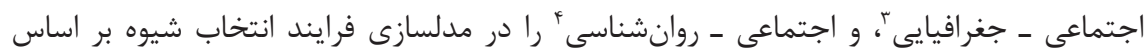

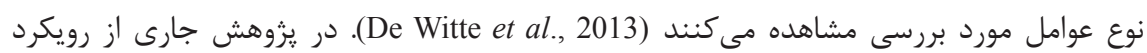
منطقى گرايان و نظريه رفتار برنامهريزىشده استفاده مىشود.

\section{روشناسى يثزوهش}

بيشتر مدلهاى انتخاب بر اساس نظريه اقتصادى مطلوبيت تصادفىه شكل مى گيرند. تلفيق

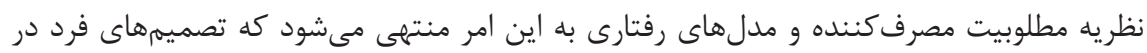

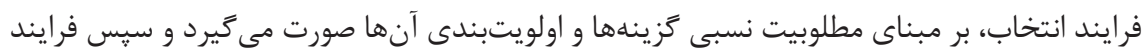

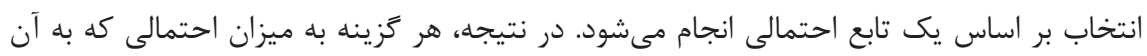

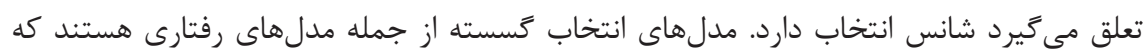

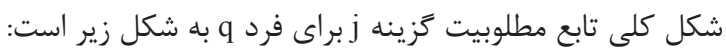
$\mathrm{U}_{\mathrm{jq}}=\mathrm{V}_{\mathrm{jq}}+\varepsilon_{\mathrm{jq}}$

1. De Witte et al.

2. Rationalist Approach

3. Socio-Geographical Approach 


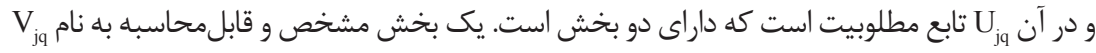
كه بر اساس ويزگى هاى فرد تصميمَير تعيين مىشود. يك بخش احتمالاتى ع عستند كه نشاندهنده خطاها و سلايق خاص افراد مورد مطالعه است. در يروهش حاضر، براى تحليل عوامل موثر بر تعداد دفعات همر اهى دانشآموز تامدرسه توسط والدين، مدل انتخاب گسسته لوجيت رتبهاى ساخته و يرداخته ميىشود.

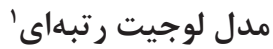

اگر متغير وابسته به صورت ترتيبى باشد، از مدلهاى رتبهاى براى برآورد يارامترها استفاده

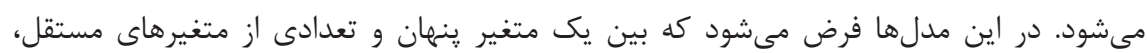
رابطهاى به صورت رابطه (r) وجود دارد (Mehdizadeh et al., 2018):

$\boldsymbol{y}_{i}{ }_{i}=\beta x_{i}+\varepsilon_{i}$

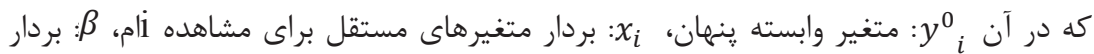

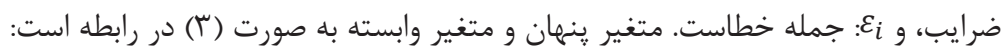
$y_{i}=m \cdot \mu_{m-1} \leq y_{i}^{0} \leq \mu_{m}$

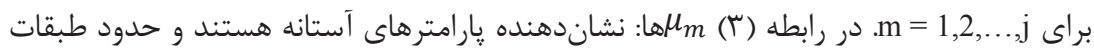
كوناگون را تعيين مى كنند. در مدل لوجيت رتبهاى شيب متغيرهاى مستقل در همه طبقات يكسان

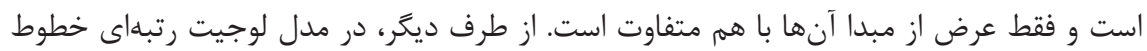
ركرسيون موازى با عرض از مبداهاى متفاوت وجود دارد. به همين دليل، مدلهاى رتبهاى به الكوهاى

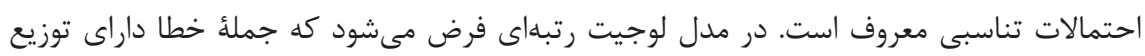
حدى با ميانگين صفر و واريانس تعريف مىشوند:

$$
\begin{aligned}
& f(\varepsilon)=\frac{e^{\varepsilon}}{\left[1+e^{\varepsilon}\right]^{2}} \\
& F(\varepsilon)=\frac{e^{\varepsilon}}{\left[1+e^{\varepsilon}\right]}
\end{aligned}
$$

هدف از يرداخت مدلهاى انتخاب گسسته شناسايى متغيرهاى توضيحى تابع مطلوبيت و تعيين ضرايب و ميزان اهميت هر يك از آنهاست. در يزوهش حاضر، ماهيت گسسته و رتبهاى متغير وابسته

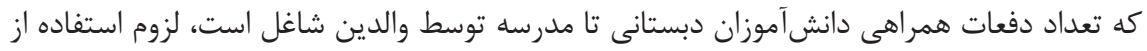


مدل لوجيت رتبهاى را نشان مىدهد. براى يرداخت مدلهاى لوجيت از روش بيشينه درستنمايى

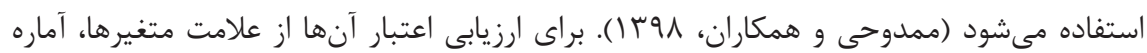

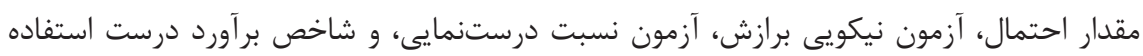

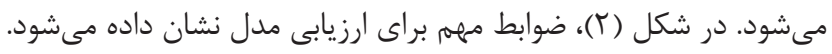

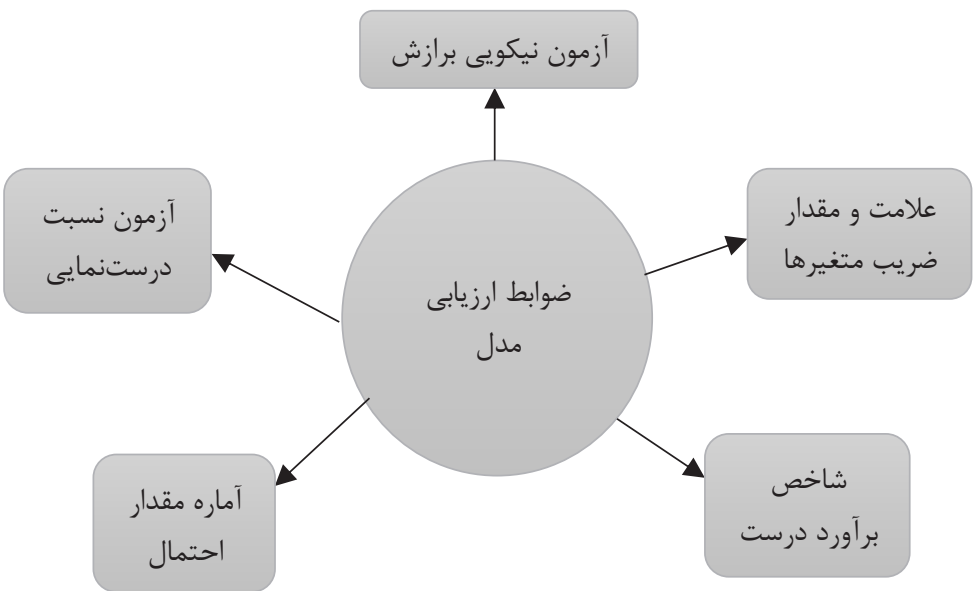

شكل r: ضوابط مهم براى ارزيابى مدل لوجيت ساختهشه

كردآورى داده سفرهاى تحصيلى ضرورىترين قدم براى تحليل رفتارهاى همراهى دانشآموزان در

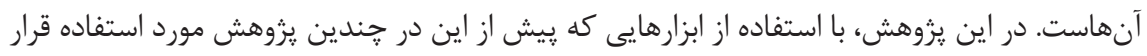

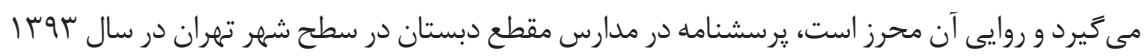

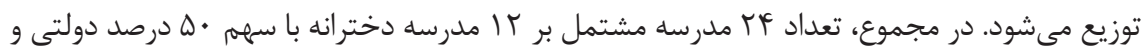

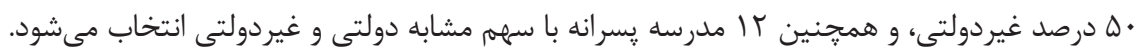

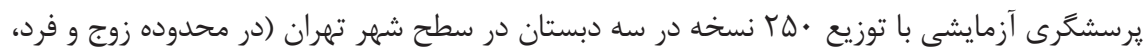
در محدوده طرح ترافيك، و خارج از محدوده كنترل ترافيك)، با نرخ بازگشت ول و درصد و انجام مصاحبه

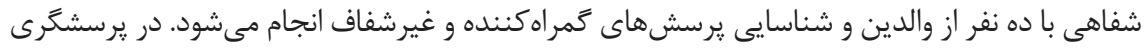




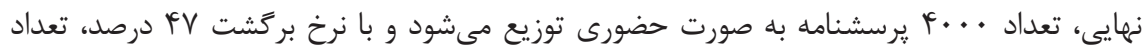

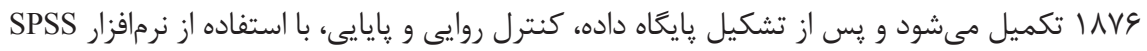

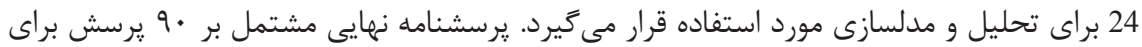
كردآورى دادهاى مربوط به متغيرهاى روانشناختى نظريه رفتار برنامهريزىشده براى استفاده از وسايل حملونقل همكانى، خودروى شخصى، و پيادهروى در سفرهاى كارى ـ تحصيلى روزانه، و متغيرهاى مرى مشابه در خصوص همراهى فرزندان تا مدرسه، عادت و ويزگگىهاى اجتماعى ـ اقتصادى و فردى است.

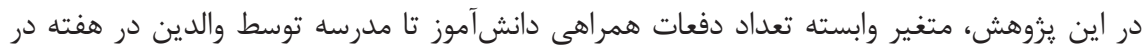

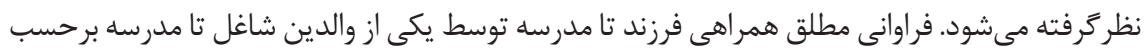

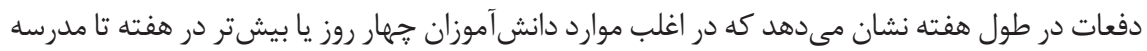

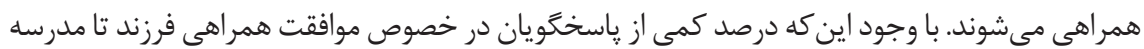

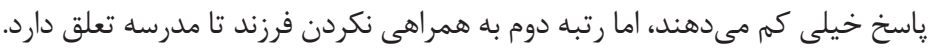

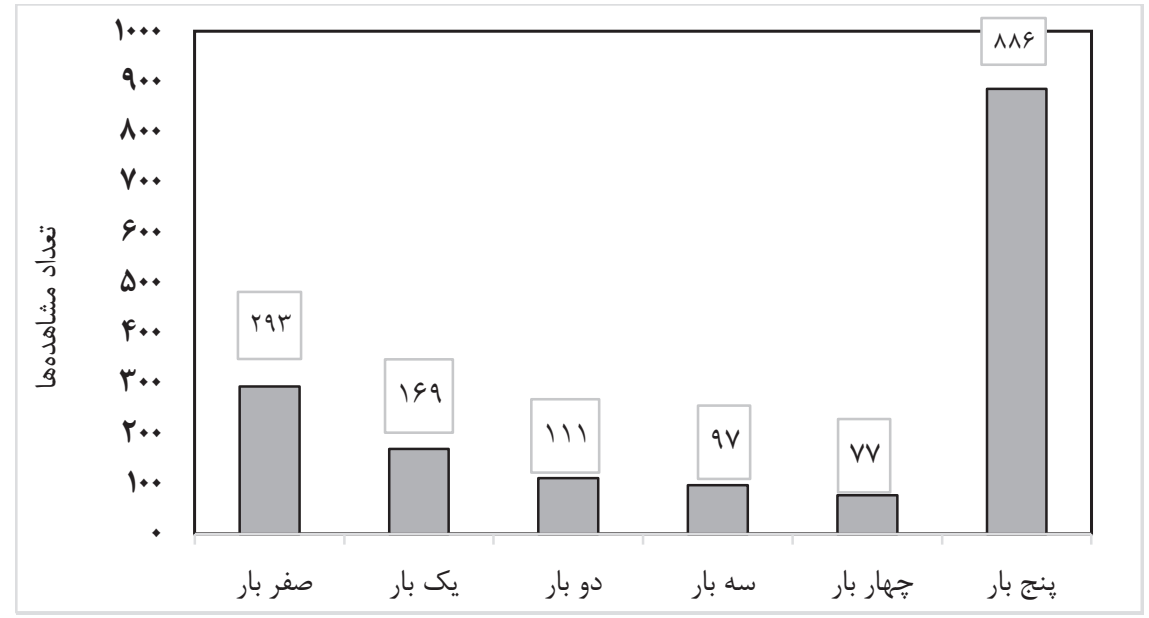
شكل "ז: فر اوانى مطلق همر اهى فرزند تا مدرسه توسط والدين در هفته

در جدول ( (1)، متغيرهاى مستقل اعم از متغيرهاى اقتصادى ـ اجتماعى و فردى، ويزگگ هاى سفر،

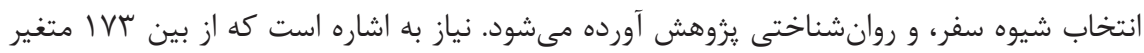
آزمايششده در مدل لوجيت رتبهاى، 9 متغير زير معنادار هستند. 
جدول ا: تعريف برخى متغيرهاى مستقل بثوهش مورد استفاده در مدل لوجيت رتبهاى

متغير مت متغير

اكر شباهت كم مسير و زمان آغاز سفر تحصيلى و

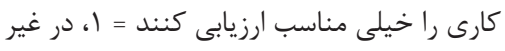

شباهت خيلى كم زمان شروع و مسير

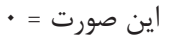

سفرهاى تحصيلى و كارى D1simtr

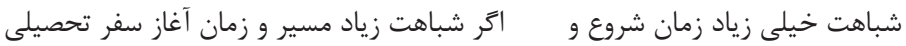

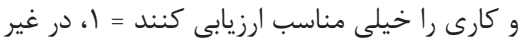

اين صورت = •

مسير مسير سفرهاى تحصيلى و كارى زمرع

D5simtr

مسافت دركشده خيلى زياد تا مدرسه اتر مسافت از خانه تا محل كار به نظر خيلى زياد

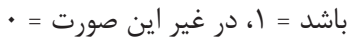

$$
\begin{aligned}
& \text { اكر مسافت از خانه تا محل كار به نظر خيلى زياد }
\end{aligned}
$$

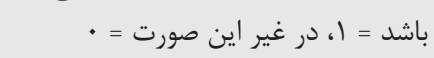

$$
\begin{aligned}
& \text { قصد همراهى } \\
& \text { Lintesc } \\
& \text { امتياز عاملى كنترل رفتارى دركشده به همراهى } \\
& \text { كنترل رفتارى دركشده نسبت به همراهى } \\
& \text { Lpbcesc } \\
& \text { سن دانشآموز به صورت پِيوسته } \\
& \text { سن دانش آموز } \\
& \text { Childage } \\
& \text { اكر شرايط فرد ديخر خانواده براى همراهى فرزند } \\
& \text { وجود فرد خيلى مناسب ديخر در } \\
& \text { را خيلى مناسب ارزيابى كنند = ا، در غير اين } \\
& \text { • صورت = ابى }
\end{aligned}
$$

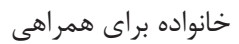

$$
\begin{aligned}
& \text { D5propesc }
\end{aligned}
$$

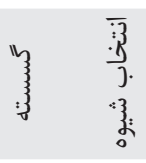

$$
\text { D5farsch }
$$$$
\text { 3. }
$$

در جدول (Y)، مشاهده مىشود كه ميانگين سنى فرزندان 9/9 و با انحراف معيار (T/ و ميانگين

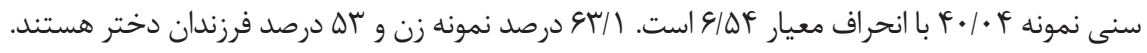

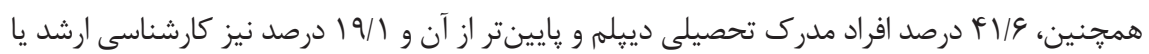


بالاتر هستند. Q/9 درصد افراد بدون خودروى شخصى، VD/T درصد افراد يك خودروى شخصى، و 1N/9

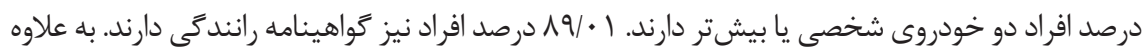

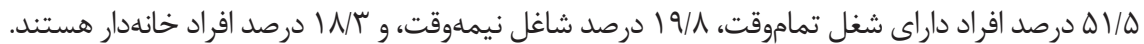

جدول ب: نتايج تحليل آمارى توصيفى متغيرهاى اجتماعى ـ اقتصادى نمونه ئوهش

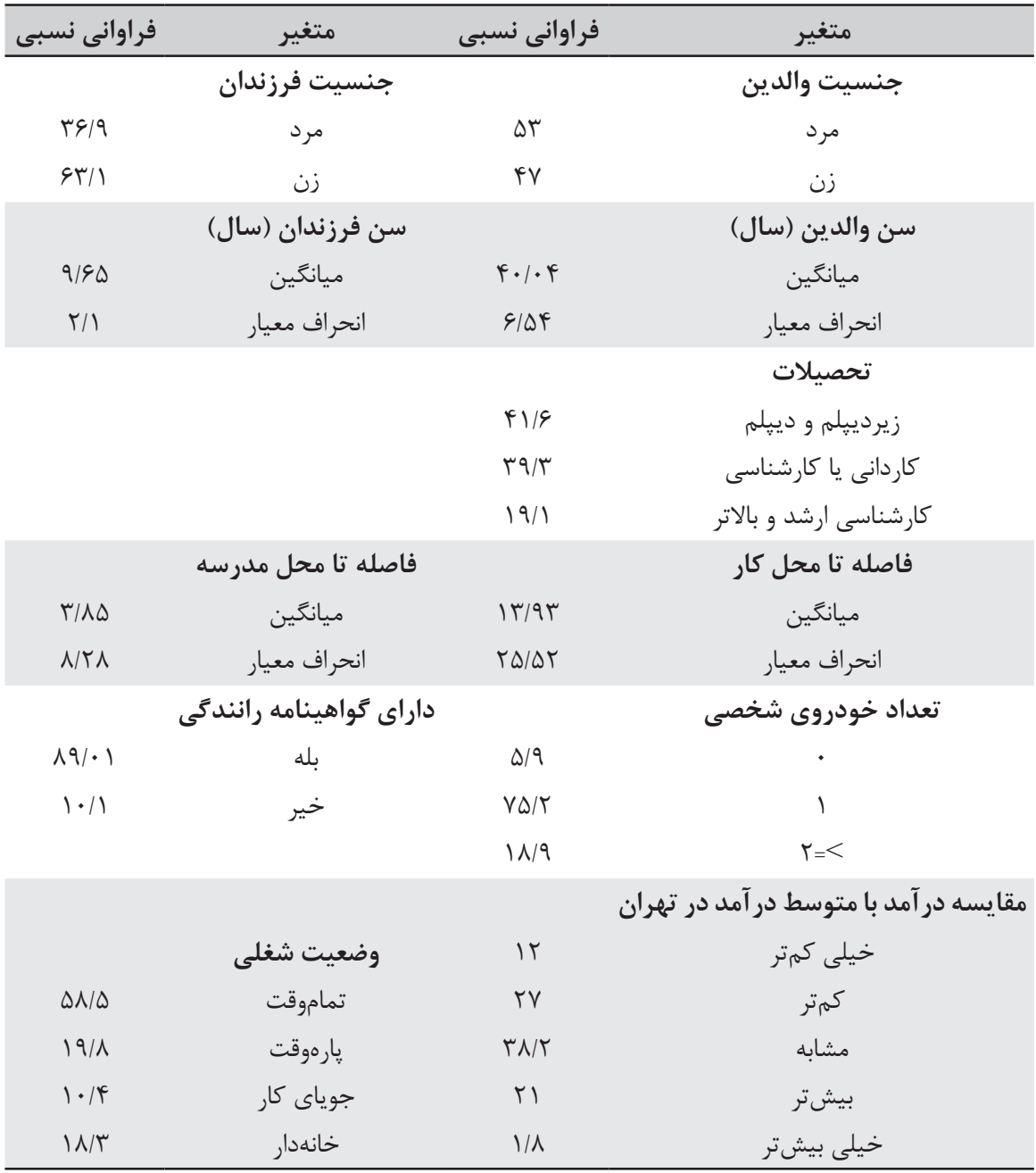




\section{مدلسازى}

دار اين بخش، نتايج يرداخت بيش از . 19 مدل لوجيت رتبهاى با استفاده از نرمافزار Nlogit5

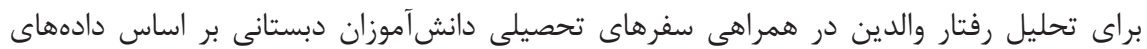

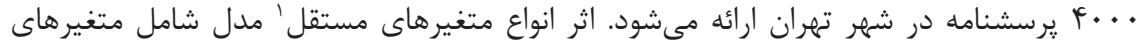

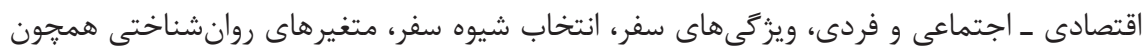
نكرش، هنجار، كنترل رفتارى دركشده، و قصد و متغيرهاى تركيبى به صورت گسسته، يِيوسته،

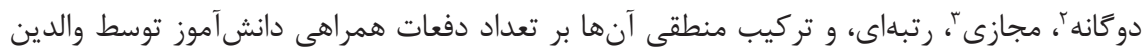
از خانه تا مدرسه در هفته به عنوان متغير وابسته مورد بررسى قرار مى گيرند. در نهايت مدل با علامت منطقى و آماره مورد يذيرش، ضرايب تابع مطلوبيت و بيشترين بهبود در مقدار لمًاريتم تابع

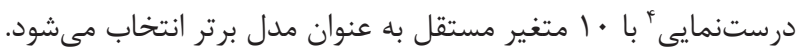

جدول سّ: نتايج يرداخت مدل لوجيت رتبهاى بر ایى تعداد دفعات همراهى در هفته

\begin{tabular}{|c|c|c|}
\hline 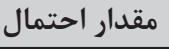 & 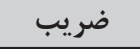 & توضيح متغير \\
\hline$\cdot 1 \cdots$ & $\cdot / 9 \Delta r^{*}$ & ثابت \\
\hline$\cdot 1 \cdots$ & 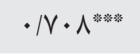 & شباهت خيلى كم زمان شروع و مسير سفرهاى تحصيلى و كارى \\
\hline$\cdot 1 \cdot \cdots$ & • & شباهت خيلى زياد زمان شروع و مسير سفرهاى تحصيلى و كارى \\
\hline$\cdot 1 \cdots$ & . $194 r^{* * * *}$ & مسافت دركشده تا مدرسه \\
\hline$\cdot 1 \cdots$ & 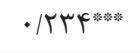 & قصد همراهى \\
\hline$\cdot 1 \cdots$ & 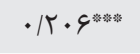 & كنترل رفتارى دركشده نسبت به همراهى \\
\hline$\cdot 1 \cdot \cdots$ & $\cdot 1 \cdot \wedge 9^{\text {粦素 }}$ & سن دانش آموز \\
\hline$\cdot 1 \cdots$ & 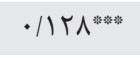 & تعداد دفعات سفر به مدرسه با خودروى شخصى \\
\hline$\cdot 1 \cdot 94$ & 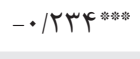 & وجود فرد خيلى مناسب ديخر در خانواده براى همراهى \\
\hline .1 .94 & $-\cdot 1 \cdot \cdot 9 *$ & مسافت تا محل كار × تحصيلات \\
\hline
\end{tabular}

نكته: ** و

1. Independent

2. Binary

3. Dummy

4. Likelihood Function 
جدول † معيارهاى ارزيابى مدل لوجيت رتبهاى

\begin{tabular}{|c|c|c|}
\hline \multicolumn{3}{|c|}{ معيارهاى ارزيابى مدل لوجيت رتبهاى } \\
\hline $\operatorname{LL}(\mathrm{C})=-19 r 9 / r \wedge$. & $\operatorname{LL}(0)=-\mid V \vee q / \cdot r r$ & $\operatorname{LL}(\beta)=-|r \wedge| / \wedge r \wedge$ \\
\hline $\begin{array}{l}\rho_{\text {adj }}^{2}=\cdot / 1 \Delta \cdot \\
\rho_{\text {adj }}^{2}=\cdot / 1 \uparrow q\end{array}$ & $\begin{array}{l}\rho_{0}^{2}=\cdot / r \cdot q \\
\rho_{\text {adj }}^{2}=\cdot / r \cdot r\end{array}$ & 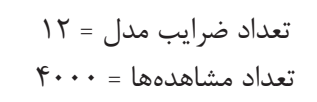 \\
\hline $\begin{array}{c}r *(\operatorname{LL}(C)-\operatorname{LL}(\beta))=r \wedge \Lambda / q \cdot r \\
\chi_{(10,0 / 01)}^{2}=r r / r \mid\end{array}$ & $\begin{array}{c}r^{*}(\operatorname{LL}(0)-\operatorname{LL}(\beta))=V \Psi \mathcal{F} / \mathcal{} \\
\chi_{(12,0 / 01)}^{2}=r \xi / T r\end{array}$ & $\begin{array}{c}\text { II = تعداد متغيرهاى مستقل ثعداد ثابت = } 11 \\
\text { تعاد }\end{array}$ \\
\hline
\end{tabular}

آماره مقدار احتمال مدل براى همه متغيرهاى معنادار كمتر از ه درصد، و بهجز براى وجود فرد مناسب و متغير تركيبى كمتر از V درصد است، و اين بدان معناست كه احتمال نبود ارتباط بين نمونه

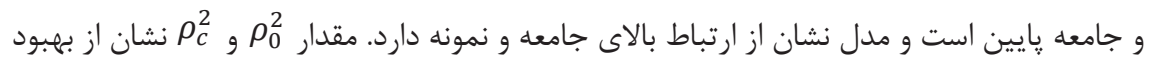

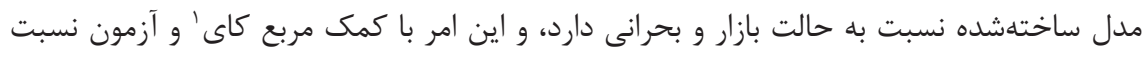

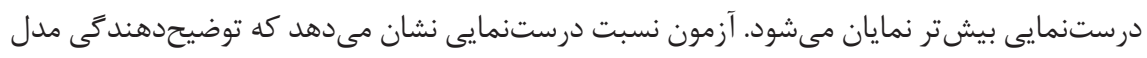

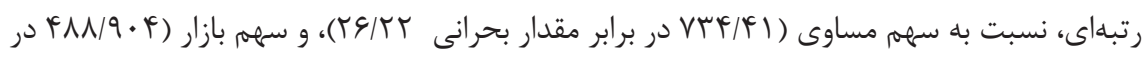

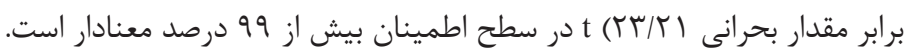

\section{تحليل نتايج مدل لوجيت رتبهاى}

بر اساس نتايج مدلهاى لوجيت رتبهاى بر آ متغير مستقل، در مدل نهايى 9 متغير كه بررسى و تحليل آنها انجام مىشود، معنادار هستند. مسافت دركشده خيلى زياد تا مدرسه: علامت اين متغير در مدل مثبت (

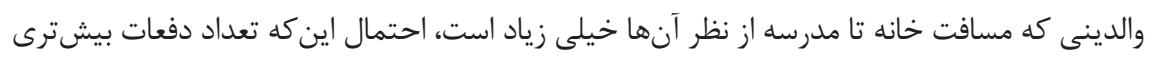
فرزند خود را تا مدرسه همر اهى كنند، بالاتر است. مى توان به اين موضوع اشاره داشت كه درك والدين از

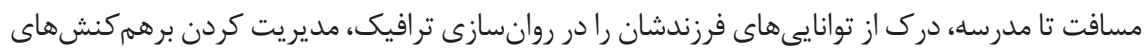

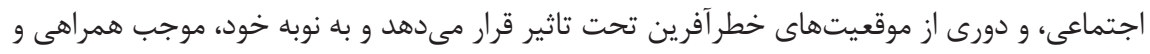

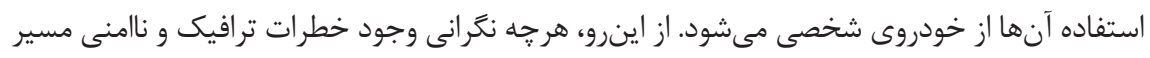

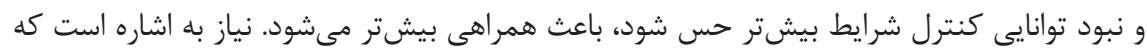

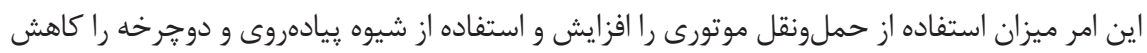


مى دهد. اين متغير با مقدار بالايى (9Tr/ •)، بيشترين اثر را بر متغير وابسته دارد.

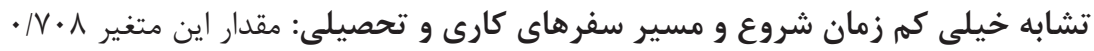

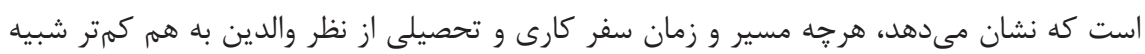

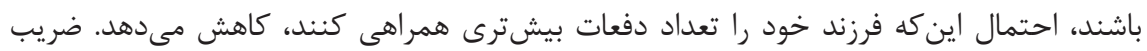

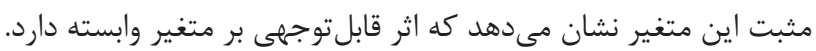

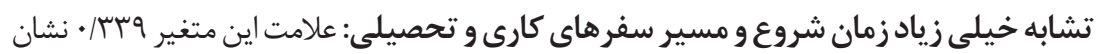
مى دهد كه هر جه مسير و زمان سفر كارى و تحصيلى از نظر والدين به هم بيشتر شبيه بـ باشند، احتمال اين كه

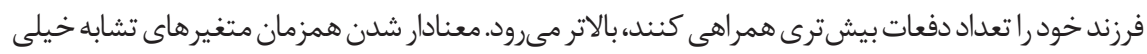

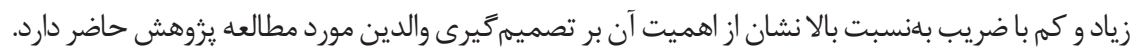

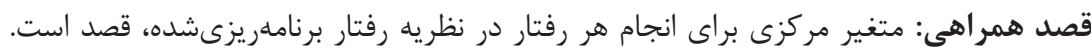

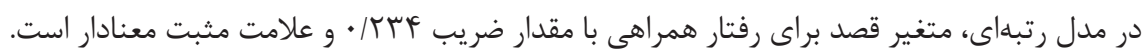

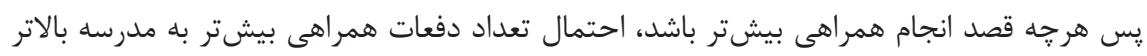

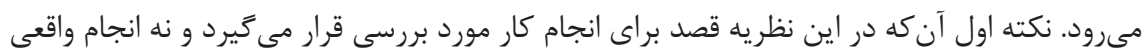
كار. ساخت مدل نشان مى دهد كه در هر صورت، بالا رفتن قصد همراهى موجب انجام واقعى رفتار

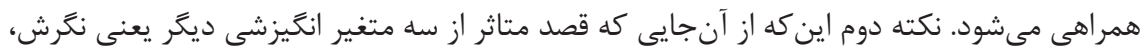

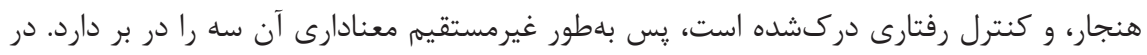

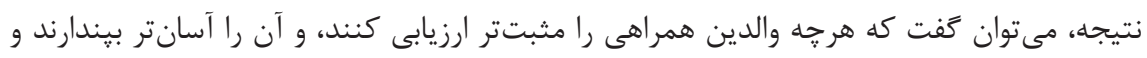
اطرافيانشان آنها را به اين كار بيشتر تشويق نمايند، قصد بيشترى براى همراهى دارند و احتمال

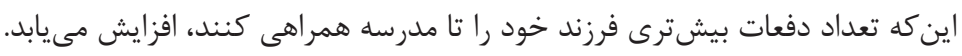

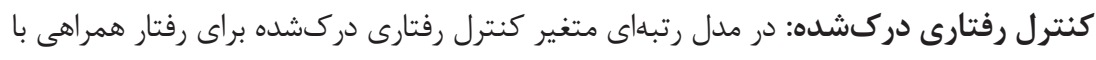

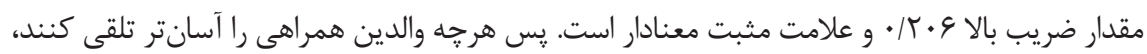

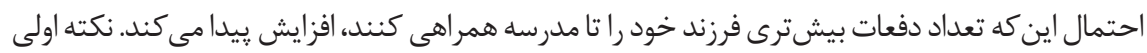

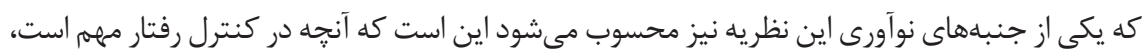

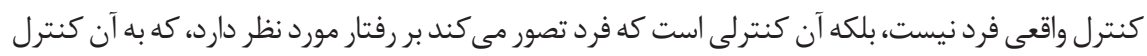
رفتار دركشده اطلاق مىشود. نكته دوم اين كه طبق نظريه، اكر كنترل كافى روى رفتار وجود داشته باشد،

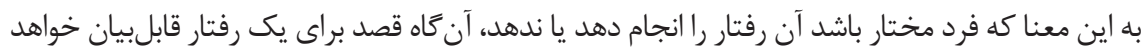

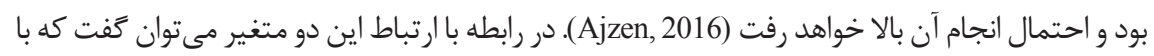


ثابت نحَه داشتن قصد، افزايش موفقيت در انجام يك رفتار با افزايش كنترل رفتار دركشده افزايش مىيابد.

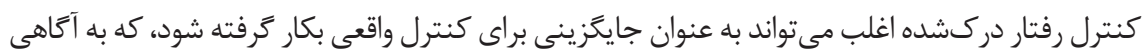
فرد در مورد عوامل تاثير گذار بر رفتار بستخى دارد. براى مثال، در شرايطى كه نيازمندىهاو منابع تغيير

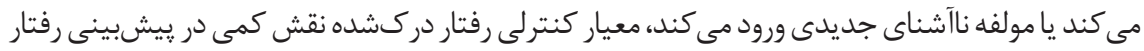
ايفا مى كند. در نتيجه، با معنادار شدن متغير كنترل رفتارى دركشده، متغير قصد قابل بيان است و اين نشان

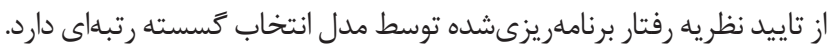

شرايط خيلى مناسب فرد ديكر خانواده براى همر اهى: با توجه به علامت منفى اين متغير

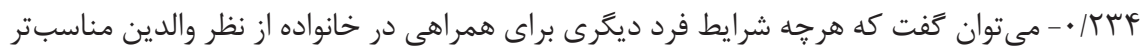

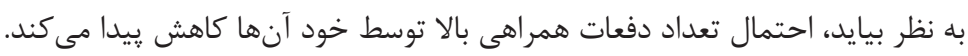

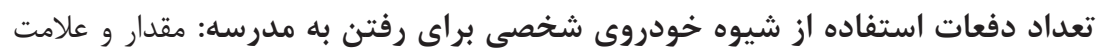

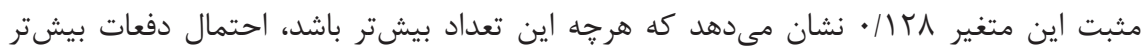

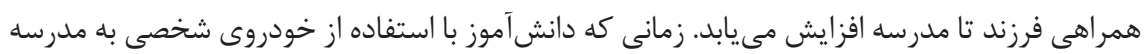

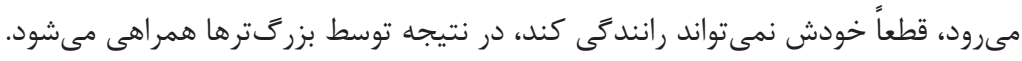

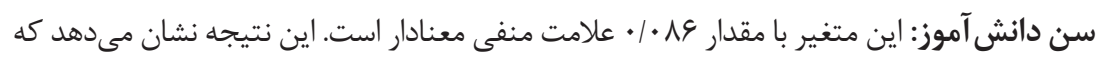
هرجه سن دانشآموز كمتر باشد، احتمال اين كه تعداد دفعات بيشترى تا مدرسه همراهى شود، افزايش

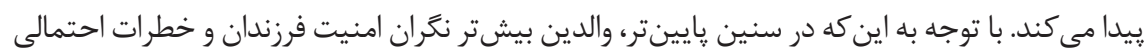

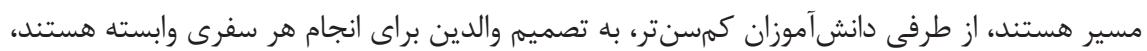

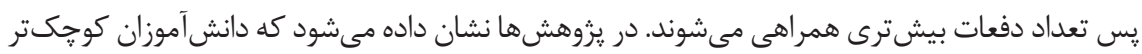

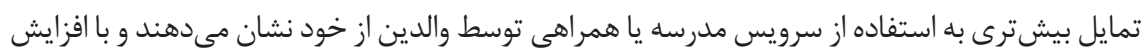

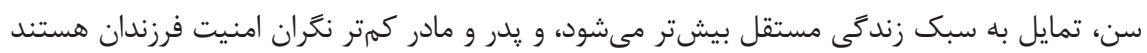
(Yarlagadda \& Srinivasan, 2008). همجنين، كودكان بزركتر از 11 سال، تعداد دفعات كمترى با استفاده از خودروى شخصى به مدرسه مىروند و بيشتر از كودكان كمسنتر بهطور فعال سفر مى كنند (Mehdizadeh et al., 2019) سرويس مدرسه دارند، و تمايل كمترى به همراهى والدين در سفرهاى رفتوبر گشت نشان مى دهند.

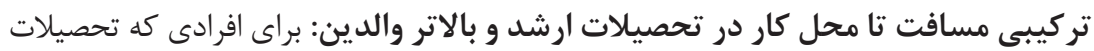
كارشناسى ارشد و بالاتر دارند، با افزايش يك واحد مساحت از خانه تا محل كار، مطلوبيت همراهى با مان

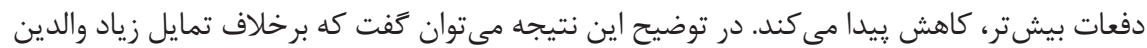


دانشآموخته براى همراهى، كه در يزوهشهاى ييشين نيز به آن اشاره مىشود، دورى مسافت تا محل

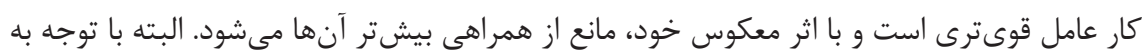
مقدار ضريب كم و • • • •-. اين اثر زياد نيست.

در مدلهاى رتبهاى، اثر حاشيهاى به نسبت ميزان تغييرهاى احتمال انتخاب كزينه مورد نظر به يك ع ع ع.

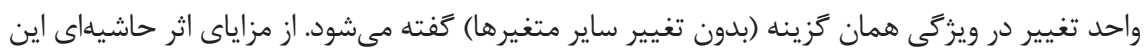

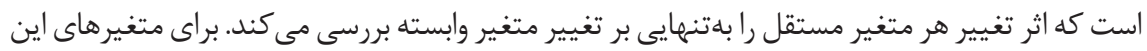
يزوهش كه از نوع رتبهاى، مجازى، گسسته، و يِيوستهاند، اثر حاشيهاى بر كشش ترجيح داده مىشود. با توجه به بررسى اثر حاشيهاى همه متغيرها در هر دو مدل به تحليل نتايج يرداخته مىشود (جدول 9) جدول \&: نتايج تحليل اثر حاشيهاى مدل لوجيت رتبهاى

انتخاب متغير

. /9TrT

$-\cdot$ ATSV

$-\cdot 1 \cdot \Delta \cdot \Delta 9$

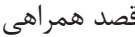

$\cdot / \cdot 1119$

$-\cdot / \cdot r R \& V$

$-\cdot 1 \cdot \operatorname{kprq}$

كنترل رفتارى دركشده همراهى

$\cdot 1 \cdot 0119$

$-\cdot / \cdot$ TMFt

$-\cdot / \cdot r V V D$

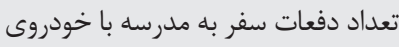

$-\cdot \cdot$ MATH

$\cdot 1 \cdot 1099$

$\cdot / \cdot 1 \wedge \Delta 9$

شخصى ( )

$-\cdot / 4 V I N$

$\cdot / \cdot \vee \backslash \wedge \Delta$

$\cdot / r \cdot r$

سن دانشآموز

+ r

$-\cdot 1890 \mathrm{Pr}$

. .901 سفرهاى تحصيلى و كارى

- ITrTH

$-.1990 \mathrm{r}$

$-\cdot 1 \cdot 9 \Delta \Lambda 1$

شباهت خيلى زياد زمان شروع و مسير تحميلى ناري سفرهاى تحصيلى و كارى

$\cdot / \pi 11 \cdot 0$

$-\cdot / 190 \cdot 1$

$-.111098$

مسافت دركشده خيلى زياد تا مدرسه

$-\cdot / \cdot \cdot T \Delta Y$

$\cdot 1 \cdot .119$

$\cdot \cdot \cdot 1 r V$

مسافت تا محل كار × تحصيلات كارشناسى ارشد و بالاتر

$\cdot / \cdot \Delta F T I$

$-\cdot / \cdot$ rata

$-\cdot / \cdot r \wedge 91$

انتخاب شيوه همكانى در صورت شباهت التش و بالثر

149 
همانطور كه در جدول (9) ديده مى نوده، با يك واحد افزايش در متغير قصد رفتارى، احتمال

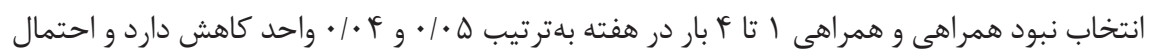

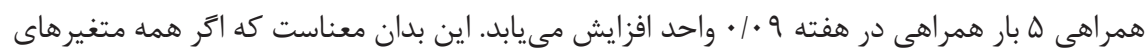

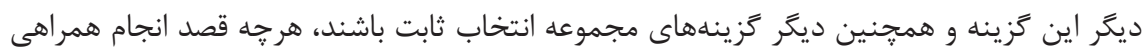

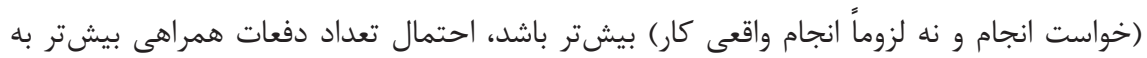

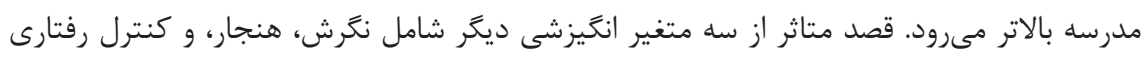

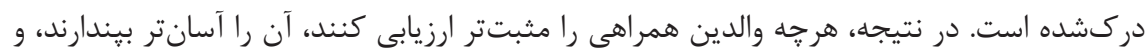

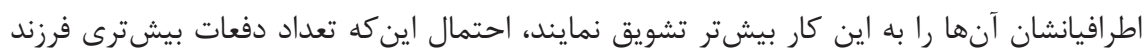

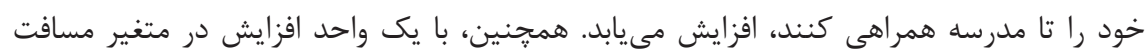

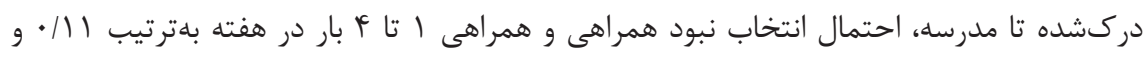

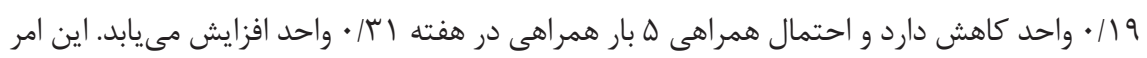

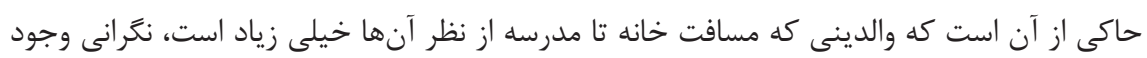

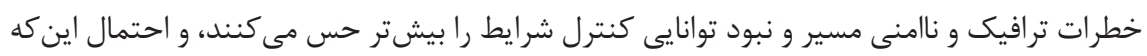

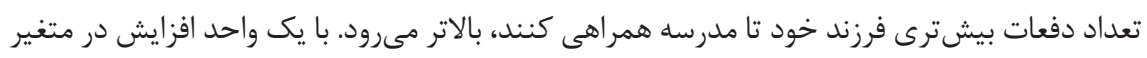

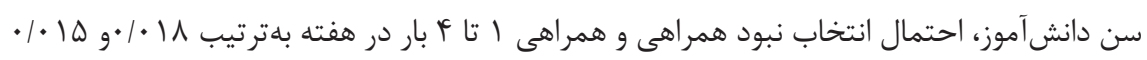

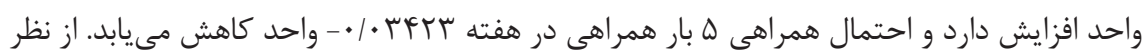

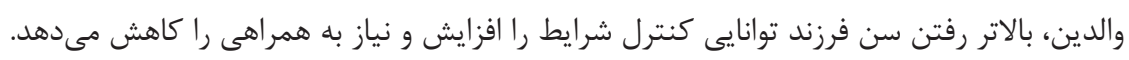

\section{بحث و نتيجه}

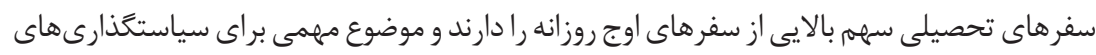

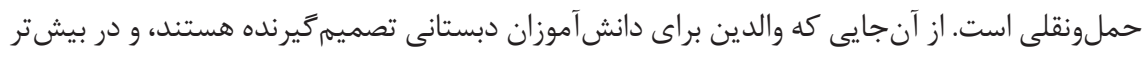

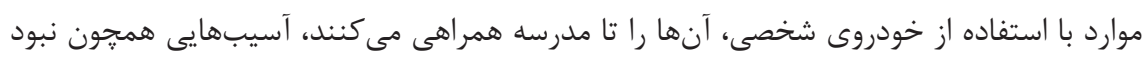

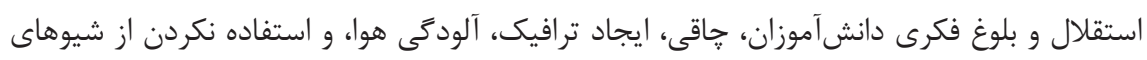

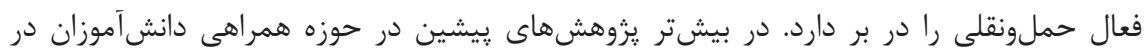

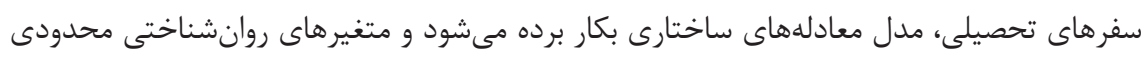

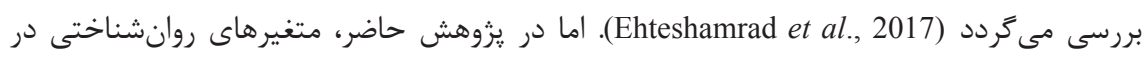


حارجوب مفهومى نظريه رفتار برنامهريزى بكار برده مىشود، و مدل لوجيت كه برخلاف معادلههاى

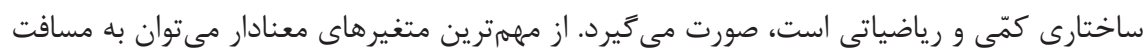
دركشده تا مدرسه، تشابه زمان شروع و مسير سفرهاى كارى و تحصيلى، قصد همراهى، كنترل رفتارى دركشده، انتخاب شيوه همعانى در صورت تشابه مسير سفر تحصيلى و كارى، و سن دانشآموز اشاره نمود. معنادارى متغيرهاى روانشناختى نشان از اهميت متغيرهاى روانشناختى دارد و لزوم توجه به آن در يروهشها و سياستخذارىها را مشخص مى منمايد. علاوه بر تحليل متغيرها در مدل، تحليل حساسيت صورت مى گيرد و معنادارى متغيرها به صورت مستقل بررسى و اهميت متغيرهاى معنادار تاييد مىشود.

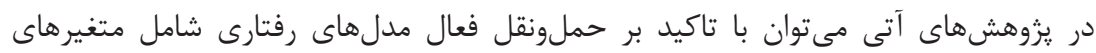
روانشناختى و با استفاده از تحليلهايى همجون مدل معادلههاى ساختارى و ديكر مدل هاى انتخاب

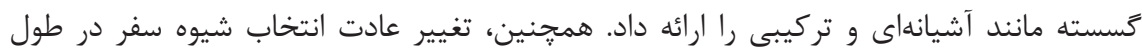
زندگى قابلبررسى است. توسعه يرسشنامه اين يزوهش شامل پرسشهايى در مورد دوجرخهسوارى و اتوبوس ويادهروى كودكان، و بررسى متغيرهاى روانشناختى مربوط به كودكان و برهمكنش و اثرگيرى آنها از والدين در تصميمگيرى براى سفرهاى تحصيلى بيشنهاد مىشود. شناخت عوامل

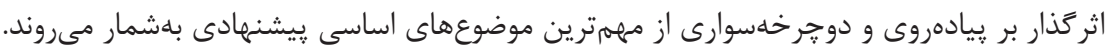

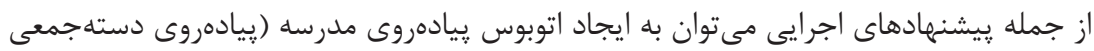
كودكان تا مدرسه با نظارت بزركترها)، و شهركهاى مسكونى نزديك محل كار والدين و مدرسه فرزندان به منظور افزايش احتمال انتخاب شيوههاى غيرموتورى اشاره نمود. افزايش انكَيزه والدين

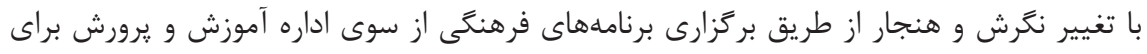

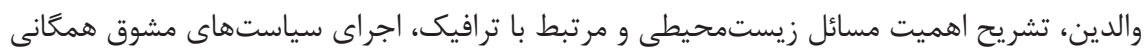
و شيوه فعال همزمان با سياستهاى بازدارنده براى كاهش استفاده از خودروى شخصى، رسيدىى

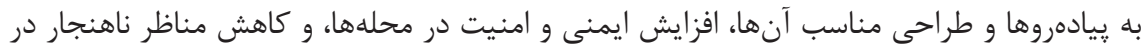

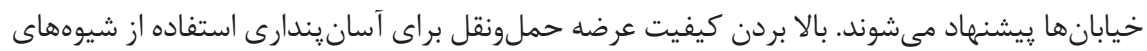

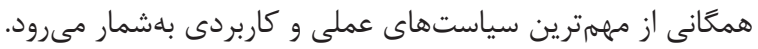


(2017). Does Parental Support Influence Children's Active School Travel? Preventive Medicine Reports, 6(1), 346-351.

McDonald, N. C., \& Aalborg, A. E. (2009). Why Parents Drive Children to School: Implications for Safe Routes to School Programs. Journal of the American Planning Association, 75(3), 331-342.

McMillan, T. E. (2007). The Relative Influence of Urban Form on a Child's Travel Mode to School. Transportation Research Part A: Policy and Practice, 41(1), 69-79.

Mehdizadeh, M., Mamdoohi, A. R., Zavareh, M. F., \& Nordfjærn, T. (2016). The Role of Parental Attitudes towards Walking on Children Walking to Schools. Journal of Traffic and Logistics Engineering, 4(2), 108-112.

Mehdizadeh, M., Nordfjaern, T., \& Mamdoohi, A. (2018). The Role of Socio-Economic, Built Environment and Psychological Factors in Parental Mode Choice for Their Children in an Iranian Setting. Transportation, 45(2), 523-543.

Mehdizadeh, M., Nordfjaern, T., \& Mamdoohi, A. (2019). Environmental Norms and Sustainable Transport Mode Choice on Children's School Travels: The Norm-Activation Theory. International Journal of Sustainable Transportation, 14(2), 137-149.

Scheiner, J., Huber, O., \& Lohmüller, S. (2019). Children's Independent Travel To and From Primary School: Evidence from a Suburban Town in Germany. Transportation Research Part A: Policy and Practice, 120(1), 116-131.

Smith, M., Ikeda, E., Hawley, G., Mavoa, S., Hosking, J., Egli, V., . . Amann, R. (2020). An Integrated Conceptual Model of Environmental Needs for New Zealand Children's Active Travel to School. Journal of Transport \& Health, 16, 100814.

Stark, J., Bartana, I. B., Fritz, A., Unbehaun, W., \& Hössinger, R. (2018). The Influence of External Factors on Children's Travel Mode: A Comparison of School Trips and NonSchool Trips. Journal of Transport Geography, 68(1), 55-66.

Westman, J., Friman, M., \& Olsson, L. E. (2017). What Drives Them to Drive?-Parents' Reasons for Choosing the Car to Take Their Children to School. Frontiers in Psychology, $8(1), 1-13$.

Yarlagadda, A. K., \& Srinivasan, S. (2008). Modeling Children's School Travel Mode and Parental Escort Decisions. Transportation, 35(2), 201-218. 